\title{
16
}

\section{Publish, Don't Perish: A Program to Help Scholars Flourish}

\section{Tara Gray}

New Mexico State University

\section{Jane Birch}

Brigham Young University

Faculty often believe that if they do not publish, they will perish. Faculty developers can respond to this need by belping faculty increase their scholarly productivity. Research showes that faculty are more productive if they write for 15-30 minutes daily, organize their writing around key sentences, and get extensive feedback on drafts. This article evaluates a program hosted on two campuses that aimed at supporting 115 faculty achieve these goals. Throughout the program, participants kept records of time they spent writing and the number of pages they wrote and at the end of the program, they were surveyed. These data reveal that if participants continued to write and revise prose at the rate they did during the program, they would produce 75 polished pages per year. According to survey results, $83 \%$ of participants would participate in the program again, and $95 \%$ would recommend it to their colleagues.

\section{INTRODUCTION}

This essay evaluates the extent to which "Publish, Don't Perish," a program designed to help faculty flourish as writers, enabled participants to achieve the following three program goals: 1) Improve time management by developing the discipline to write daily for at least $15-30 \mathrm{~min}$ utes; 2 ) improve writing by learning to organize each paragraph, section, and paper around a key sentence; and 3) improve writing by seeking feedback within a community of scholars. These outcomes were measured by 
records faculty participants kept of their time spent writing, and their subsequent levels of productivity, and by a participant survey administered at the conclusion of the program.

For many faculty, scholarship is an important coin of the realm, with both short- and long-term purchasing power. The phrase "publish or perish" refers to the impact scholarly productivity may exert in faculty hiring and firing, promotion, and access to resources. Scholarly productivity is typically measured by the number of articles published in peer-reviewed journals, with those published in the top-tier journals receiving the strongest weighting. While much criticism has been justly targeted at measures that reduce productivity to a simple head count of articles published in peer-reviewed journals, this measure has become the de facto standard at many institutions and is unlikely to change in the near future (Bellas \& Toutkoushian, 1999). Given the importance of scholarly productivity, faculty developers can play an important role in assisting faculty by providing programmatic support for their scholarly efforts. The question becomes, "How can faculty developers help faculty improve their scholarly productivity?"

Some research suggests that patterns of productivity are difficult to change because the more productive scholars have already acquired a cumulative advantage which cannot be matched by their less productive colleagues. According to this school of thought, productive scholars gain an early advantage which leads to positive outcomes (e.g., developing an early interest in research), and increased opportunities (mentoring by a prominent scholar, publishing early, etc.), that compound the early advantage and lead to further advantages (receiving a faculty appointment in research institutions, developing extensive collegial networks, and so forth) (Creamer \& McGuire, 1998). Indeed, although many factors affect scholarly productivity, relatively few can be readily altered by the faculty member. Table 16.1 illustrates the variety of factors that affect productivity. Note that many are either fixed or beyond the faculty member's ability to change. Gender, for example, is fixed, and once a terminal degree is acquired, so is much of one's educational background.

However, other researchers point out that attitudes and behaviors are within a scholar's ability to change and may be among the strongest and most persistent factors affecting productivity (Blackburn \& Lawrence, 1995). Because attitudes and behavior can be changed, they are of particular interest to faculty developers who work in the area of scholarly productivity. Boice $(1987,1989,1991,1992,1994,1996)$ is one faculty developer whose pioneer research in scholarly productivity has led to 
TABLE 16.1

Factors Affecting Scholarly Productivity

\begin{tabular}{|c|c|c|}
\hline Personal Factors & Examples of Factors & Relevant Citations \\
\hline $\begin{array}{l}\text { Innate personal } \\
\text { characteristics }\end{array}$ & $\begin{array}{l}\text { Age } \\
\text { Gender } \\
\text { Race } \\
\text { IQ }\end{array}$ & $\begin{array}{l}\text { Astin \& Davis, } 1985 \\
\text { Bellas \& Toutkoushian, } 1999\end{array}$ \\
\hline $\begin{array}{l}\text { Personal and fam- } \\
\text { ily background }\end{array}$ & $\begin{array}{l}\text { Socioeconomic origins } \\
\text { Marital status } \\
\text { Size of family }\end{array}$ & Bellas \& Toutkoushian, 1999 \\
\hline $\begin{array}{l}\text { Educational back- } \\
\text { ground and } \\
\text { opportunities }\end{array}$ & $\begin{array}{l}\text { Type of degree acquired } \\
\text { Time spent acquiring the degree } \\
\text { Quality of the institution } \\
\text { Academic field }\end{array}$ & Bentley \& Blackburn, 1990 \\
\hline $\begin{array}{l}\text { Professional ex- } \\
\text { perience and } \\
\text { opportunities }\end{array}$ & $\begin{array}{l}\text { Postdoctoral fellowship } \\
\text { Employment in research institution } \\
\text { Extensive collegial networks } \\
\text { Mentoring by a prominent scholar } \\
\text { Academic rank } \\
\text { Years of experience } \\
\text { Number of grants } \\
\text { Tenure }\end{array}$ & $\begin{array}{l}\text { Blackburn, Behymer \& Hall, } \\
1978 \\
\text { Creamer \& McGuire, } 1998\end{array}$ \\
\hline $\begin{array}{l}\text { Current profes- } \\
\text { sional context }\end{array}$ & $\begin{array}{l}\text { Academic discipline and milieu } \\
\text { Quality of the institution } \\
\text { Geographical location } \\
\text { Publication norms } \\
\text { Social support } \\
\text { Work stress } \\
\text { Workload and schedule }\end{array}$ & $\begin{array}{l}\text { Blackburn \& Lawrence, } 1995 \\
\text { Neumann \& Finaly- } \\
\quad \text { Neumann, } 1990 \\
\text { Ramsden, } 1994 \\
\text { Wanner, Lewis, \& Gregorio, } \\
\quad 1981\end{array}$ \\
\hline $\begin{array}{l}\text { Attitudes and } \\
\text { behaviors }\end{array}$ & $\begin{array}{l}\text { Disposition } \\
\text { Commitment to research } \\
\text { Percentage of time spent on research } \\
\text { Number of journal subscriptions } \\
\text { Number of hours worked } \\
\text { Time management }\end{array}$ & $\begin{array}{l}\text { Creamer \& McGuire, } 1998 \\
\text { Bellas \& Toutkoushian, } 1999 \\
\text { Boice, } 1992 \\
\text { Blackburn \& Lawrence, } 1995\end{array}$ \\
\hline
\end{tabular}

helping faculty address the specific attitudes and behaviors that lead to greater scholarly productivity.

Boice observed that some faculty publish far more than others and that these faculty differ in both their attitudes and behavior. These faculty complain little about busyness; they seem more positive and less stressed about their jobs. As teachers, they set limits on the time they spend on lecture preparation, limiting it to about half what other faculty 
spend, and yet students consider them more effective teachers. As scholars, they write during more weeks of the semester, including the busiest weeks. They rarely write in binges (except for grant writing). They actively solicit advice about both teaching and research. And they receive feedback on their writing when it is still in its formative stages.

Boice also studied factors that inhibit scholarly productivity, including the perception among faculty that they are too busy to publish. When he asked 108 new faculty at a regional university whether or not this was the busiest year of their lives, $55 \%$ of the faculty surveyed answered, "yes". After faculty were asked to keep careful records of their workweeks, however, most were "forthright with admissions that they were not nearly as busy as they had supposed" (Boice, 1992, p. 17). They discovered that they rarely had days without some free period, which they usually used for a low-priority activity such as reading mail or talking on the phone.

In addition to feeling too busy, Boice found that many faculty believed they could not write unless they could isolate big blocks of time (Boice, 1987, 1989). However, "big" blocks of time are precisely what most faculty do not have. When faculty wait for big blocks of time, first they wait for summer, then sabbatical, then retirement (Boice, 1992, p. 18). Boice's research led him to propose that faculty can be productive if they find ways to write daily for at least 15-30 minutes. By writing daily, researchers keep the flame of their research alive because their writing becomes part of their daily thinking, which means they are ready to write when their next writing session arrives.

The faculty development programs Boice piloted confirmed that faculty could greatly increase their scholarly productivity by writing daily and by being held accountable for doing so. In his studies, a control group wrote as they always had, but an experimental group wrote daily for 30 minutes. In one study, only $19 \%$ of the controls completed a paper in a year, but $75 \%$ of the experimentals did (Boice, 1996, p. 90). In another study, faculty who set aside 30 minutes a day to write drafted or revised almost 64 pages in a year, which was almost four times the productivity (17 pages) of the control group (Boice, 1989, p. 609). In the same study, Boice had a second experimental group who agreed to write daily and accept biweekly visits from him during the blocks of time that they had agreed to write. This group wrote or revised 157 pages per year, which was more than twice as much as those who agreed to write daily but were not visited (64 pages) (Boice, 1989, p. 609).

Working in the tradition of Boice, Gray developed a semester-long 
faculty development program aimed at helping faculty increase their scholarly productivity. Like the programs directed by Boice, faculty were held accountable for writing 15-30 minutes a day. Faculty were also encouraged to take other steps aimed at improving their attitudes and behavior regarding writing. These 12 steps to scholarly productivity, which are published elsewhere (Gray, 1999), focus on having faith in oneself as a writer, and then taking steps to improve time management, writing strategies, and seeking regular help from others (see Table 16.2).

These 12 steps serve as the subject of the first half of the six-hour opening workshop for participants in the semester-long program: "Publish, Don't Perish-A Program to Help Scholars Flourish." The second half of the opening workshop is aimed at helping faculty improve their writing, especially in terms of organizing paragraphs around key sentences and seeking feedback from others in a community of scholars.

\section{Methods}

In the spring of 1998, the program was founded under the direction of Gray at New Mexico State University; the following year, it was repeated there and also piloted at Brigham Young University, under the direction of both Gray and Birch. In the three versions of "Publish, Don't Perish," a total of 115 faculty completed the semester-long program, with an average retention rate of $75 \%$. Table 16.3 describes demographic characteristics of the participants.

At New Mexico State University, participants were recruited by means of a flier that was sent to all 750 faculty. This flier invited faculty to enroll as a participant and a research subject for a stipend of $\$ 100$. Initially, 63 faculty responded to the flier and enrolled. Because this was twice the expected number, separate sections were held for technical and nontechnical writers. In the first year at New Mexico State University, 38 faculty completed the program, for a $60 \%$ completion rate.

The semester-long program had several components, including opening and closing workshops as well as roundtables every other week. During these roundtables, participants met in small groups to give and receive feedback on their writing. Participants seemed to work in groups that were only loosely clustered by discipline; i.e., some groups seemed to have mostly scientists or engineers, but if those groups were full, participants moved to other groups. In the first year, no leadership was provided for the groups. Some of the groups were enormously successful, but others were not. The program director believed that if leadership were provided 
TABLE 16.2

Twelve Steps to Scholarly Productivity

1) Believe you have something to say.

\section{Time Management Strategies}

2) Become a manager of your time, not a victim of it.

3) Differentiate between the urgent and the important.

4) Write at least 15-30 minutes daily.

\section{Writing Strategies}

5) Work on one project at a time-until you gain some momentum.

6) Don't finish the literature review first: read as you write, and write as you read.

7) Organize each paragraph, section, and paper around a key sentence.

\section{Get Help From Colleagues}

8) Hold yourself accountable to others.

9) Share early drafts with trusted colleagues.

10) Listen carefully to criticism, repeat it back, and suggest a change you might make in response.

11) Develop thick skin-really thick.

12) Kick it out the door and make 'em say "no."

to give focus and direction to the groups, participants would have a better experience, and the completion rate would improve. Therefore, in the second year, eight successful alumni of the program were enlisted to serve as group leaders and these leaders received extra training before the program opened. Under the direction of group leaders, groups seemed more focused, and the completion rate for the second year at New Mexico State University improved from 60 to $70 \%$ (28 out of 40 ).

Brigham Young University is twice the size of New Mexico State University, so invitations were extended only to junior faculty. An overenrollment was expected, so the tone of the invitation was stern: Please do not enroll unless you are committed to meeting the full requirements of the semester-long program. Faculty members were not paid but, as expected, the program was popular as soon as it was advertised. Two hundred junior faculty were invited to participate, and over $25 \%$ wanted to enroll. Due to space limitations, only 43 were admitted. Forty-one of these participants persisted throughout the semester at Brigham Young University, for a completion rate of $95 \%$.

Data from all three versions of the program are presented here, which include data from records participants kept regarding when and how much they wrote and a survey of the participants at the end of the program (the completion rate for the survey varied between $93 \%$ and $100 \%$ ). 
TABLE 16.3

Characteristics of Participants

\begin{tabular}{|c|c|c|c|c|}
\hline & Average & $\begin{array}{c}\text { NMSU } \\
1998\end{array}$ & $\begin{array}{c}\text { NMSU } \\
1999\end{array}$ & $\begin{array}{l}\text { BYU } \\
1999\end{array}$ \\
\hline Participants & 38 & 38 & 36 & 41 \\
\hline \multicolumn{5}{|l|}{ Gender } \\
\hline Male & $46 \%$ & $45 \%$ & $39 \%$ & $54 \%$ \\
\hline Female & $54 \%$ & $55 \%$ & $61 \%$ & $46 \%$ \\
\hline \multicolumn{5}{|l|}{ Tenured } \\
\hline Yes & $19 \%$ & $32 \%$ & $25 \%$ & $0 \%$ \\
\hline No & $81 \%$ & $68 \%$ & $75 \%$ & $100 \%$ \\
\hline \multicolumn{5}{|l|}{ Time as college professor } \\
\hline $1-6$ years & $72 \%$ & $55 \%$ & $72 \%$ & $90 \%$ \\
\hline $7-15$ years & $21 \%$ & $34 \%$ & $22 \%$ & $8 \%$ \\
\hline $20-30$ years & $6 \%$ & $10 \%$ & $6 \%$ & $2 \%$ \\
\hline \multicolumn{5}{|l|}{ Research Area } \\
\hline Arts/Humanities & $24 \%$ & $24 \%$ & $12 \%$ & $37 \%$ \\
\hline Science/Engineering & $22 \%$ & $18 \%$ & $22 \%$ & $27 \%$ \\
\hline Agriculture & $13 \%$ & $21 \%$ & $17 \%$ & $0 \%$ \\
\hline Education & $9 \%$ & $5 \%$ & $6 \%$ & $15 \%$ \\
\hline Social Sciences & $9 \%$ & $8 \%$ & $14 \%$ & $5 \%$ \\
\hline Health/Social Services & $7 \%$ & $5 \%$ & $3 \%$ & $12 \%$ \\
\hline Business & $4 \%$ & $0 \%$ & $11 \%$ & $2 \%$ \\
\hline Other & $12 \%$ & $18 \%$ & $17 \%$ & $2 \%$ \\
\hline
\end{tabular}

An important limitation of the study is that all the data come from participants, and no attempt was made to compare the scholarship produced by participants to nonparticipants. This limitation could be corrected in future studies by comparing the productivity of participants to nonparticipants. However, if the study were to compare the number of publications resulting from the writing during the program period, both groups would have to be studied for a period extending after the program ended.

\section{Publish, Don't Perish: Goals and Goal Attainment}

The "Publish, Don't Perish" program helps faculty:

1) Improve time management by developing the discipline to write daily for at least 15 to 30 minutes

2) Improve writing by learning to organize each paragraph, section, and paper around a key sentence

3) Improve writing by seeking feedback within a community of scholars 


\section{Results for Goal \# 1}

Improve time management by writing daily for at least 15 to 30 minutes. Based on Boice's research, as discussed earlier, participants in "Publish, Don't Perish" were encouraged to use two techniques: 1) Write daily for at least 15 to 30 minutes, and 2) hold themselves accountable for doing so. In the program orientation, participants were exposed to research about the effectiveness of both techniques. Participants were then required to keep records on the time of day and number of minutes they spent writing. These records were submitted every other week to their group leaders at the roundtables. By keeping records of their time spent writing, participants were held accountable, especially to themselves.

By self report, participants wrote an average of two days a week and averaged 27 minutes a day for each day in the workweek. At this rate, participants were able to produce 1.5 new pages per week and to revise another 1.5 pages. If participants continued this pace of writing and revising for a year, they could produce 75 pages, or about three journal articles a year (see Table 16.4).

At the end of the semester, participants were asked to agree or disagree with statements that asserted the program had helped them improve their time management. For each statement about time management, at least $63 \%$ of participants agreed (see Table 16.5). Their comments indicated that the program helped them because it prompted them to write daily, and to be accountable to other members of their group:

"The most important skill I learned was the habit of writing for a halfhour first thing when I get to work. I completed two papers (both accepted) and the rough draft of a paper that has been hanging over my head for years. And much of this was accomplished in a half-hour per day."

"I personally needed the direction to come each week and be asked, 'How'd it go?' 'What did you do?' 'Why didn't you do as planned?'Just baving to tell someone the silly excuses I have for not working on my research would help me quit allowing it to happen."

"What helped me the most was just the accountability to other people. I submitted two manuscripts this semester, and I never could have done that without the aid of the workshop."

More faculty, however, commented on another form of accountability that helped them-recording the time they spent writing on writing worksheets: 
TABLE 16.4

Achievement of Goal \# 1-Writing Daily for at Least 15 to 30 Minutes: Data from Records Kept by Participants

\begin{tabular}{lcccc}
\hline Goal & Average & $\begin{array}{c}\text { NMSU } \\
1998\end{array}$ & $\begin{array}{c}\text { NMSU } \\
1999\end{array}$ & $\begin{array}{r}\text { BYU } \\
1999\end{array}$ \\
\hline Writing five days/week & & & & \\
$\quad$ Mean (days/week) & 2.1 & 1.4 & 2.1 & 2.9 \\
$\quad$ Range* (days/week) & 5.2 & 4.5 & 4.5 & 6.5 \\
Writing 15-30 minutes/day & & & & \\
$\quad$ Mean (minutes/day) & 27 & 15 & 27 & 40 \\
Range* (minutes/day) & 201 & 72 & 87 & 444 \\
Writing 1-3 new pages/week & & & & \\
Mean (new pages/week) & 1.5 & 1.4 & .9 & 2.1 \\
Range* (new pages/week) & 10.8 & 11.5 & 4.0 & 17.0 \\
\hline
\end{tabular}

*The minimum reported for each range was always zero, so only the upper value of the range is shown.

\section{TABLE 16.5}

Achievement of Goal \# 1-Improving Time Management: Percent Agreeing on the Survey of Participants

\begin{tabular}{lcccc}
\hline Statement & Average & $\begin{array}{c}\text { NMSU } \\
1998\end{array}$ & $\begin{array}{c}\text { NMSU } \\
1999\end{array}$ & $\begin{array}{c}\text { BYU } \\
1999\end{array}$ \\
\hline $\begin{array}{l}\text { I feel less victimized by my busy schedule. } \\
\text { I am more realistic about how I spend my } \\
\quad \text { time and where it goes. }\end{array}$ & $6.3 \%$ & $53 \%$ & $69 \%$ & $68 \%$ \\
$\begin{array}{l}\text { My scholarship was aided by the process } \\
\text { of filling out and turning in writing } \\
\text { worksheets. }\end{array}$ & $63 \%$ & $42 \%$ & $61 \%$ & $86 \%$ \\
\begin{tabular}{l} 
I am a better time manager. \\
\hline
\end{tabular} & $67 \%$ & $55 \%$ & $67 \%$ & $78 \%$ \\
\hline
\end{tabular}

"The writing worksheets were like a silent sentinel!!"

"They gave me a weapon to combat procrastination."

"They reminded me to write. And reminded me that I had written."

"I liked having it taped above my desk. It motivated me to sit dozen for a fere minutes so I could reward myself by noting the time."

The majority view was that productivity was improved by writing daily, keeping daily records, and being accountable to one's group. However, a 
few participants disagreed about the value of writing worksheets, especially in the first year of the program. These comments included,

"Writing worksheets were not at all helpful. It was paperwork and had the same onus as the Federal Income Tax!"

"I had some writing periods and some nonwriting periods this semester. During the writing periods, the worksheets belped keep me going and reminded me of my commitment. During the nonwriting periods, they were an irritation and induced guilt."

\section{Results for Goal \#2: Improve Writing by Learning to Organize Each Paragraph, Section, and Paper around a Key Sentence.} "Publish, Don't Perish" helped participants improve their writing by learning to organize each paragraph, section, and paper around a key sentence. This technique can be taught in a few hours, and half of the sixhour opening workshop for the program is devoted to learning how to apply the technique to one's own prose, as well as that of other participants. Then, participants use the technique throughout the semester at the roundtables that occur every other week.

In the orientation, participants learn how to check the coherence of a paragraph by identifying the key sentence. The key sentence is the sentence that could be sent as a telegraph if needed in place of the part of the text for which it serves as a key (Williams \& Colomb, 1990, pp. 97-103). First, the author reads the paragraph, looking for the key sentence. If the author cannot find the key sentence, the reader will not be able to find it either and may judge the paragraph as unclear or poorly organized. If the author finds two different key sentences, two paragraphs are probably in order.

Once each paragraph has a key sentence, the author checks to ensure that each section has a key sentence and that the paper as a whole has one key sentence. Next, the author makes a list of these sentences (Booth, Colomb, \& Williams 1995, pp. 205-206). This list does not have to sound elegant because it was not written to be read this way. However, the list should be logical and coherent if the paper is well-organized. Once it is, the intent of the paper will be much clearer to the audience.

Most "Publish, Don't Perish" participants agreed that the program helped their organization, with at least $70 \%$ agreeing with each survey question aimed at assessing this goal (see Table 16.6). Many participants commented, 
TABLE 16.6

Achievement of Goal \#2-Improve Writing by Learning to Organize Each Paragraph, Section, and Paper around a Key Sentence Percent Agreeing on the Survey of Participants

\begin{tabular}{lcccc}
\hline & & NMSU & NMSU & BYU \\
Statement & Average & $\mathbf{1 9 9 8}$ & $\mathbf{1 9 9 9}$ & $\mathbf{1 9 9 9}$ \\
\hline I organize paragraphs around one key sentence. & $71 \%$ & $55 \%$ & $83 \%$ & $75 \%$ \\
I write better organized paragraphs and papers. & $70 \%$ & $55 \%$ & $78 \%$ & $78 \%$ \\
This program improved my writing. & $83 \%$ & $71 \%$ & $86 \%$ & $93 \%$ \\
\hline
\end{tabular}

"What helped me most in this program was the information on organizing paragraphs. The program brought about some much needed changes in my writing style."

"Looking for key sentences in others' writing every two weeks gave me a 'booster shot' of skills to use on my own writing."

When other groups have requested the one-hour version of this program, they invariably ask for just "the key sentence idea."

\section{Results for Goal \#3: Improve Writing by Seeking Feedback from Others within a Community of Scholars}

Most faculty realize it is important to seek feedback on scholarly writing; however, they do not seek this help as often as they should for a variety of reasons. First, faculty may think of writing as a solitary endeavor that results in something cast in stone, rather than a social activity that more nearly results in a conversation in print. In addition, faculty may not realize that feedback from readers can save them the most time on early drafts, rather than on a nearly polished product. They may even think that seeking help on drafts is time-consuming rather than time-saving. Faculty may believe that colleagues in their discipline are the only appropriate audience for their work, and they may feel it is more important to impress these colleagues than to get help from them on early drafts. Or, they may not want to impose on their busy colleagues by asking them to read drafts. And finally, they may not know how to seek help from others effectively, and as a result, they may receive help only at the sentence-level, rather than at the organizational level, which is more likely to transform prose.

In "Publish, Don't Perish," we challenge these myths and encourage faculty to experiment for themselves and discover the benefits of seeking 
early feedback from colleagues. As discussed in the last section, we teach faculty a way of looking at text in terms of paragraphs, sections, and whole papers rather than as a collection of sentences. We point out that publication can be usefully viewed as a social activity resulting in conversations in print. Viewed in this light, it is clear that one of the biggest challenges faced by writers is to clearly communicate their intent to an audience. When writers read their own writing, they are not really reading, but simply reviewing their thoughts at the time they were writing (Booth, Colomb, \& Williams 1995, p. 202).

We argue and then demonstrate that receiving feedback on early drafts is a time-saving rather than a time-consuming measure. Early drafts are more likely to elicit comments and to benefit from them (Boice, 1992, p. 29). As a result, getting help on early drafts can save writers enormous amounts of time. That is, writers can receive criticism on organization before they have spent hours perfecting the wording of each sentence, including sentences that will be deleted when the organization improves.

We also teach and then demonstrate that colleagues in one's own discipline are not the only source of good feedback. The program provides a time and place for scholars to exchange drafts across disciplines. Participants learn through experience that some of the best criticism comes from readers in other disciplines. These readers are prone to focus more on the organization and clarity of the paper since they are not familiar with the subject matter. This program provides an ideal opportunity for scholars to exchange criticism on early drafts with colleagues in other disciplines, which helps create a community of critical, yet caring scholars.

Of the three goals of the program, the survey results suggest the program was the most successful in helping participants get feedback from their colleagues, with at least $76 \%$ agreeing with each related statement (see Table 16.7). On open-ended questions, some participants commented on how other readers can see problems that the author cannot:

"Sometimes you read your paper over and over, and you think everybody will understand it just because it becomes really familiar to you but as soon as you bave somebody else reading your work you know the things that are missing."

"Feedback helps me evaluate my own writing more critically. My temptation is to fall in love with my own choice of words and phrases."

Other participants commented on the sense of community that developed, as well as how participants felt less alone in the process of writing: 


\author{
TABLE 16.7
}

Achievement of Goal \#3-Improve Writing by Seeking

Feedback from Others within a Community of Scholars:

Percent Agreeing on the Survey of Participants

\begin{tabular}{lcccc}
\hline Statement & Average & $\begin{array}{c}\text { NMSU } \\
1998\end{array}$ & $\begin{array}{c}\text { NMSU } \\
1999\end{array}$ & $\begin{array}{c}\text { BYU } \\
1999\end{array}$ \\
\hline $\begin{array}{l}\text { Ilearned how to get better feedback (by asking } \\
\quad \text { questions and repeating criticisms, etc.). }\end{array}$ & $76 \%$ & $68 \%$ & $83 \%$ & $76 \%$ \\
I received supportive feedback. & $85 \%$ & $82 \%$ & $89 \%$ & $83 \%$ \\
I received constructive criticism. & $83 \%$ & $84 \%$ & $89 \%$ & $77 \%$ \\
I received support and accountability from & $76 \%$ & $68 \%$ & $83 \%$ & $76 \%$ \\
$\quad$ others. & & & & \\
\hline
\end{tabular}

"My group was always super supportive, so they kept me very pumped."

"The best part of the program was the camaraderie with my group."

"Now I feel like a real member of the faculty here - my research is important."

"I had expected professoring to be a very lonely endeavor."

Other participants commented on how helpful it was to have readers who were outside one's own discipline:

"The feedback was quite beneficial. This is the first time in my career that someone from outside my field had read any of my work, let alone a working copy of a paper. It was very instructive."

"I liked receiving feedback from people alien to my field. Now, I actively seek such feedback. And, I encourage my graduate students to do the same."

"I was amazed that people outside my discipline could offer such incredibly insightful feedback on the organization and clarity of my zoriting."

"The reviews of my writing by non-scientists are FANTASTIC!"

In fairness, however, a few participants complained about readers: specifically, that readers outside of one's discipline were not effective:

"Though we were counseled to have readers outside of our discipline read our work, I did not feel it worked in this setting. Many of the criticisms were as misguided as my word processor's grammar checker." 
"Many of the comments were not completely relevant because they related to bow the paper could be more approachable for a 'lay' audience, when in fact it is written for specialists."

Still others felt that participants were not critical enough:

"Most of the feedback was not extremely useful; maybe they [participants] were too nice at times."

"After the first round of readings, the feedback was not as belpful as I had anticipated - much of 'this looks great' and 'I really like this."

In response to these criticisms, future versions of the program will differ in two ways: 1) They will encourage participants to join groups in which all participants have similar-but not the same-disciplines (i.e., humanities or science), and 2) they will direct more training at the importance of being critical as well as supportive. Scientists and engineers in particular want to work in groups with each other, and perhaps their writing is different enough that they should. And although faculty are prone to be harsh when they act as anonymous reviewers, they are equally prone to being too nice when placed face-to-face with a colleague. Therefore, future training will focus on providing constructive criticism.

\section{Program Assessment}

Every faculty development program is a work in progress, and this program is no exception. Nonetheless, the program was rated very highly by participants: $83 \%$ would participate in the program again, and $95 \%$ would recommend it to their colleagues (see Table 16.8). Participants commented,

"I have much more courage to send things out because of this program. It
should definitely be offered every year."
"I think [the program] should be for everybody that is new . . . and
not just an option."

\section{Conclusion}

Our experience on two very different campuses suggests that faculty are highly motivated to improve their scholarly productivity and are willing to participate in faculty development efforts designed to do so. Faculty 
TABLE 16.8

Overall Success of Program:

Percent Saying "Yes" on a Survey of Participants

\begin{tabular}{|c|c|c|c|c|}
\hline Statement & Average & $\begin{array}{l}\text { NMSU } \\
1998\end{array}$ & $\begin{array}{l}\text { NMSU } \\
1999\end{array}$ & $\begin{array}{l}\text { BYU } \\
1999\end{array}$ \\
\hline The director facilitated the program well. & $95 \%$ & * & $100 \%$ & $90 \%$ \\
\hline My group leader facilitated my group well. & $78 \%$ & $* *$ & $91 \%$ & $64 \%$ \\
\hline $\begin{array}{l}\text { I will recommend this program to my } \\
\text { colleagues. }\end{array}$ & $95 \%$ & $95 \%$ & $100 \%$ & $91 \%$ \\
\hline I would participate in this program again. & $83 \%$ & $82 \%$ & $89 \%$ & $78 \%$ \\
\hline $\begin{array}{l}\text { The Faculty Center should sponsor this } \\
\text { program again. }\end{array}$ & $92 \%$ & *** & $* * *$ & $92 \%$ \\
\hline
\end{tabular}

*In 1998, this question was not asked.

** In 1998, this question was not asked because there were no group leaders.

***This question was not asked at New Mexico State University.

developers can assist faculty with their scholarly productivity by developing programs based on research-based principles. The data from "Publish, Don't Perish" suggest that participants using the suggested techniques produced 1.5 new pages per week and revised another 1.5 pages. If scholarship were produced and revised at this pace for a year, it could potentially lead to more frequent and better quality written products.

As a result of increased productivity, successful scholarship programs generate praise and gratitude from faculty, as well as departmental, college, and university administrators who have a vested interest in scholarship. Due to the very positive response of both faculty and administrators at the two institutions discussed in this paper, both institutions plan to offer the program on an ongoing basis. Scholarship workshops can be hosted on other campuses as well. Although faculty developers traditionally focus on helping faculty improve as teachers, the time may be right to begin helping faculty more systematically with their scholarship. This valuable service to the faculty can bring added prestige to the faculty development center and thus encourage faculty to take advantage of the multitude of other services available there.

\section{REFERENCES}

Astin, H. S., \& Davis, D. E. (1985). Research productivity across the life and career cycles: Facilitators and barriers for women. In M. F. Fox (Ed.), Scholarly writing and publishing: Issues, problems, and solutions (pp. 147-160). Boulder, CO: Westview. 
Bellas, M. L., \& Toutkoushian, R. K. (1999). Faculty time allocations and research productivity: Gender, race, and family effects. The Review of Higher Education, 22 (4), 367-390.

Bentley, R., \& Blackburn, R. T. (1990). Changes in academic research performance over time: A study of institutional accumulative advantage. Research in Higher Education, 31 (4), 327-353.

Blackburn, R. T., Behymer, C. E., \& Hall, D. E. (1978, April). Research note: Correlates of faculty publications. Sociology of Education, 51, 132-141.

Blackburn, R. T., \& Lawrence, J. H. (1995). Faculty at work: Motivation, expectation, satisfaction. Baltimore, MD: Johns Hopkins University.

Boice, R. (1987). Is released time an effective component of faculty development programs? Research in Higher Education, 26 (3), 311-326.

Boice, R. (1989). Procrastination, busyness, and bingeing. Behavior Research Therapy, $27(6), 605-611$.

Boice, R. (1991). Quick starters: New faculty who succeed. New Directions for Teaching and Learning, No. 48. San Francisco, CA: Jossey-Bass.

Boice, R. (1992). Strategies for enhancing scholarly productivity. In J. F. Moxley (Ed.), Writing and publishing for academic authors (pp. 15-32). New York, NY: University Press of America.

Boice, R. (1994). How writers journey to comfort and fluency. Westport, CT: Praeger.

Boice, R. (1996). Procrastination and blocking: A novel, practical approach. Westport, CT: Praeger.

Booth, W. C., Colomb, G. G., \& Williams, J. M. (1995). The craft of research. Chicago, IL: University of Chicago Press.

Creamer, E. G., \& McGuire, S. P. (1998). Applying the cumulative advantage perspective to scholarly writers in higher education. The Review of Higher Education, 22 (1), 73-82.

Gray, T. (1999). Publish, don't perish: Twelve steps to help scholars flourish. Journal of Staff, Program, and Organization Development, 16(3), 135-142.

Moxley, J. M. (1992). Publish, don't perish: Scholar's guide to academic writing and publishing. Westport, CT: Praeger.

Neumann, Y., \& Finaly-Neumann, E. (1990). The support-stress paradigm and faculty research publication. Joumal of Higher Education, 61 (5), 565-578.

Ramsden, P. (1994). Describing and explaining research productivity. Higher Education, 28, 207-226. 
Wanner, R. A., Lewis, L. S., \& Gregorio, D. I. (1981, October). Research productivity in academia: A comparative study of the sciences, social sciences and humanities. Sociology of Education, 54, 238-253.

Williams, J., \& Colomb, G. (1990). Style: Toweard clarity and grace. Chicago, IL: University of Chicago Press.

Contacts:

Tara Gray

Associate Professor

Department of Criminal Justice

New Mexico State University

Las Cruces, NM 88003-8001

(505) 646-1013

(505) 646-2827 (Fax)

Email: tgray@nmsu.edu

Tara Gray serves as Associate Professor of Criminal Justice at New Mexico State University. She has a strong interest in helping faculty collaborate as teachers and scholars. To this end, she regularly gives workshops at universities across the country.

Jane Birch

Program Coordinator

Faculty Center

Brigham Young University

Provo, UT 84602

(801) 378-4008

(801) 378-7467 (Fax)

Email: jane_birch@byu.edu

Jane Birch is Program Coordinator at the Brigham Young University Faculty Center. Among her responsibilities, she directs the BYU Faculty Development Series, an intensive 18-month new faculty program. Her main interest and passion lies in helping faculty make connections between their religious faith and their work as teachers and scholars. 